\title{
Scientific Management Movements in Pre-War Japan
}

\author{
By Satoshi Sasaki \\ Meiji University
}

\section{Introduction}

Introduction and development of scientific management in Japan contained two streams when viewed as 'movements', that is, as conscious endeavors to popularize and promote scientific management. One consisted of efforts by individuals who introduced to Japan the knowledge and literature on scientific management in America and consulted with Japanese private enterprises to increase productivity. Their activities were unified in 1927 by the establishment of the Nihon Noritsu Rengokai (National Management Association of Japan). The other stream involved the policies and movements promoted by the government independently from those in the private sector. This latter stream energetically pressed for scientific management after the creation of the Rinji Sangyo Gorikyoku (Provisional Industrial Rationalization Bureau) in 1930, especially using as a propelling force the Nihon Kogyo Kyokai (Japanese Industrial Association) founded in 1931 .

The former stream may be regarded as a scientific management movement by business consultants and independent experts in this field, while the latter was a movement by government and business leaders. But the two streams grew closer to each other until the former completely engulfed the latter. As a result, the Nihon Noritsu Kyokai (Japanese Management Association) was born in 1942 with the express purpose of guiding the unified movement.

Concerning scientific management in Japan, past studies ${ }^{1}$ touched on examples in individual enterprises or on movements in the private sector, but they failed to canvass government policies and involvement of the business community which represented the country's "economic interests." 2 Consequently, no comprehensive study exists today of the introduction and development of scientific management in Japan as a whole.

In this article, I will examine the Japanese government's and big business's knowledge of scientific management as well as their policy implementation from the 1910s, when heavy industry developed in 
Japan, through the early 1930s. In other words, this work includes the scientific management movement launched by government and business leaders. It pays special attention to people who actively participated in the movement. This approach is without doubt essential to research in business history. Further, an in-depth study of the men in the movement is an important key to understanding how the respective movements of the government and the business community cooperated with one another and came in the end to complement each other.

\section{Examples of Scientific Factory Management}

Introduction of scientific management and examples of its early application in Japan are found both in state and private enterprises. Among the state-owned enterprises, the National Railways and the Navy Dockyard in Kure are the foremost examples.

Nationalization of railways in 1906 necessitated reorganizing the hitherto segmented management patterns into a systematic and unified plan. The National Railways, therefore, launched "modernization" and "rationalization" of management by creating a new repair plant as well as standardizing steam locomotives and carriages. It also introduced work flow management based on a master schedule on the one hand and a foreman system on the other. As shown below, the history and results of the National Railways' use of such "scientific" management was reported in the 5th Division (Division on Railways and Transportation) of the World Engineering Congress held in Tokyo in 1929. The report attracted much attention from various participating nations. ${ }^{3}$

The Kure Naval Dockyard, which operated against the background of the 8-8 fleet plan launched immediately after World War I, ${ }^{4}$ adopted the limit gauge system for efficient mass production of interchangeable parts. It also introduced route sheet, instruction card, and stop watch to measure work time. The Central Planning Division created in 1921 clarified the loci of authority and responsibility, at the same time improving the method of scheduling, "start" control, cost management, material management, time study, and quality control. The results were reported, as in the case of the National Railways, in the 12th Division (Scientific Management Division) of the World Engineering Congress. ${ }^{5}$

It is noteworthy that Okiie Yamashita and Takuo Godo, the chief advocates of scientific shop management at the National Railways 
and the Kure Naval Dockyard, respectively, later became the pivotal figures in the scientific management movement instituted by the government. Their contribution suggests that the precedents set for scientific management by the National Railways and the Kure Naval Dockyard were more systematic than those found in the private sector - indeed, sufficiently so to serve as the prototype of later movements.

In the private sector, the machinery and textile industries adopted scientific management. I will not discuss individual examples, but the general characteristics of scientific management in these industries may be mentioned.

In the machine industry, electric machine producers, such as Nihon Electric, Mitsubishi Electric, and Yasukawa Electric, employed scientific shop management. So did industrial machine manufacturers, such as the Niigata Ironworks, the Karatsu Ironworks, and the Ikegai Ironworks. Common to these industries that uncritically applied the method of scientific management used by American enterprises. The patterns of application were three. The first was uncustomized introduction of the techniques used by the American partners of joint ventures. The second was the attempts of plant owners and technical experts to apply scientific plant management methods they had acquired in the United States. The third was through instruction by foreign engineers working for Japanese companies that had no joint business with foreign firms.

To the first type belonged the Nihon Electric Company, which used the management system of the Western Electric Company, ${ }^{6}$ and Mitsubishi Electric, which introduced the scientific management of the Westinghouse Corporation. ${ }^{7}$ Among the second are the Kamata plant of the Niigata Ironworks, the Karatsu Ironworks, and the Yasukawa Electric Company. At the Niigata Ironworks, engineer Shigeo Kato applied the scientific management techniques he had learned at Tabor Manufacturing. ${ }^{8}$ At the Karatsu Ironworks, Toshisuke Takeo, who later owned it, used the method developed by the Stevens Institute of Technology and the three machine manufacturing firms he had visited in the United States. ${ }^{9}$ At the Yasukawa Electric, Daigoro Yasukawa introduced the premium system of Westinghouse. ${ }^{10}$ Finally, the representative example of the third type was the Ikegai Ironworks, which employed the American engineer, W.C. Francis. ${ }^{11}$

In the United States, it was the machine industry that most typically used scientific management. In Japan, too, those companies in the machine industry had access to information on scientific management 
American machine manufacturers used that management system early on without modification. The pioneer practitioners of the American method in Japan, when recognized for their work in the private sector, became the leaders of the scientific management movement.

In the case of cotton spinning firms, Kurabo, ${ }^{12}$ Kanebo, ${ }^{13}$ Toyobo, ${ }^{14}$ and Nisshinbo ${ }^{15}$ availed themselves of scientific plant management. Business concentration and mergers in the 1910s and early 1920s forced the spinning industry in general to attempt rationalization of production. Increased productivity was also paramount in the face of the prohibition of late night-shift work imposed by the revised Factory Law. Introduction of scientific management was indeed the industry's response to that prohibition and focused on time and motion study. Case studies of the spinneries mentioned above exist, but, perhaps due to insufficient sources, they present neither detailed analysis nor information on the individuals who supported new techniques of management. It is well known, however, that the idea of scientific management emphasized by those spinneries as a "spiritual revolution" became wedded to the idea of "Japanese management." It was promoted by ideologues such as Sanji Muto and produced recognizable results. ${ }^{16}$

Unlike the advocates of scientific shop management at state-owned factories and in the machine industry, few in the spinning industry became pivotal figures in the movement promoted by the government and business associations. The only notable exception was Gito Teruoka, who gained renown through research in labor science.

Outside the state-owned plants and private enterprises, there were also independent experts in efficiency study, such as Yoichi Ueno and Toichiro Araki, who played a significant role in the introduction and evolution of scientific management. Their role was threefold. The first was introducing literature on scientific movement including F.W. Taylor's works. The second was consulting at factories. The third was popularizing and promoting a grass-roots movement in the private sector.

These experts recognized the effectiveness of scientific management already in the early 1910 s and began advocating it through lectures and writing. From the end of the 1910s to the beginning of the 1920s, they collaborated with American experts, such as L. Gilbreth and K. Hathaway, to transplant knowledge and practical experience from abroad. They also consulted for Lion Tooth Paste, Nakayama Taiyodo, Fukusuke Footwear, Chiyoda Shoes and Nippon Steel. 
For the purpose of this article, especially important is the third aspect of the role of these experts. In late-developing countries like Japan, organized activities that go beyond individual voluntary efforts are necessary to introduce and popularize advanced institutions and technology from industrialized nations. Moreover, the motivating force of these activities is naturally the individuals who introduce foreign literature and have on-the-spot experience at factories. In fostering scientific management, Ueno and Araki went beyond personal efforts. They organized activities, consulted for factories, and introduced foreign literature. They not only helped establish the Kyochokai Sangyo Noritsu Kenkyujo (Institute of Industrial Efficiency in Conciliation Society) in 1922, but also laid the foundation of the scientific management movement in the private sector by respectively creating the Nihon Sangyo Noritsu Kenkyujo (Japan Industrial Efficiency Research Institute) in 1925 and Araki Noritsu Jimusho (Araki Management Institute) in 1923.

By the latter half of the 1920 s, research institutes for industrial efficiency were born in various parts of Japan, reflecting the growth of voluntary movement in the private sector. In 1927, Nihon Noritsu Kenkyukai (Japan Management Research Society), a private club to support Ueno, was formed, followed by the founding of Nihon Noritsu Rengokai (National Management Association of Japan) consisting of the Osaka Noritsu Kenkyukai, Kanagawa Noritsu Kenkyukai, Hyogo Noritsu Rengokai, Hamamatsu Noritsu Kenkyukai, and Manshu Noritsu Kenkyukai.

Ueno and Araki always stood at the forefront of the private sector's voluntary movement. In the 1930 s, their work met the approval of the government and big business associations, which had just started their own scientific movement. Ueno and Araki thus became coopted into the official movement.

\section{Government Policies and Concerns}

The scientific management movement initiated by the government blossomed after 1930, the year the Provisional Industrial Rationalization Bureau was born. Its origin, however, was found already in the early 1910 s, when the private sector started introducing foreign literature on management. How did the government deepen knowledge of scientific management in the 1910s and 1920s and what policies did it adopt to disseminate it? 
(1) Seminars for Factory Inspectors and Training of Personnel

Promulgation of the Factory Law in 1911 and its implementation in 1916 gave rise to the government's initial concern with "modern," "scientific" shop management. Interestingly, it is believed today that the concept of scientific management, too, was first introduced to Japan in 1911 by Toshiro Ikeda's book, "Mueki no tesu o habuku hiketsu" (The key to save labor).

In February and March 1916, the Ministry of Agriculture and Commerce gave a training course for local factory inspectors. The course consisting of 20 subjects included factory management. ${ }^{17}$ Although the content of the required subject is unascertainable, the Ministry of Agriculture and Commerce, seeking knowledge of scientific management, no doubt availed itself of the literature that had already been known in Japan. The training course was probably conceived as the means to spread knowledge obtained through such literature.

After the Factory Law went into effect, the government helped organize "discussion groups" in cities, towns and villages to facilitate enforcement of the law. In the 1920s, three groups served as local organs to consult for factory owners on the Factory Law. In the 1930s, however, as the government and big business associations promoted the scientific management movement, they became a network to assist that movement.

Long before legislating the Factory Law, the Ministry of Agriculture and Commerce aimed to foster a core of men "knowledgeable about commerce or trained in business and industrial technology in foreign countries" so as to "contribute to the development of our country's foreign trade." 18 To this end, the Ministry recruited 609 trainees to study business and industry abroad between 1896 and 1916. Of these, 529 completed the training program by December 1916. As many as 211 went to America, the "motherland" of scientific management. As to the areas of training, 222 recruits, the largest number, were assigned to industry. This figure included 47 trainees in the machine industry, the representative industry to introduce scientific management. Of the 529 men who returned from training abroad, 143 found employment at private firms or factories, while 40 went into government service. ${ }^{19}$

Accumulation of human resources made possible by the above training program contributed much to the introduction of scientific management. Shigeo Kato of the Niigata Ironworks and Toichiro Araki, the research scholar, who were the outstanding examples, 
transplanted into Japan the knowledge gained in America.

Thus the 1910s saw the creation of various incipient institutions, as well as fostering capable personnel, for scientific management. These developments prepared the ground for the growth and ultimate flowering of scientific management in the following two decades.

(2) Productivity Research and Product Standardization in the Textile Industry

Besides instituting the training program abroad, the government launched translation of foreign language literature on scientific management and channeled "scientific" management into factories. ${ }^{20}$ The textile industry was chosen for this purpose because it accounted for Japan's leading export goods.

The first research into productivity of this industry took place in November and December 1920 on 13 products at 47 factories in 23 prefectures. ${ }^{21}$ As shown in Table 1, the research yielded rich data on work time. While productivity was high for the textiles produced through simple manufacturing processes, such as white cotton, relatively low efficiency characterized the production of silk crepe, Kokura duck cloth, and silk pongee. It is true that this discrepancy resulted from a method of calculation that overlooked the manufacturing process. Nonetheless, the research report attributed the difference in productivity primarily to "whether or not factory owners possess the concept of efficient operation of their plants" and secondarily to "whether or not the owners' managerial knowledge, capital, and various economic relations have created operating conditions requisite to improving productivity." 22 The report also addressed in accompanying proposals "the direct and objective causes of discrepancies in productivity." The report discussed the following five factors: 1) factory layouts; 2) equipment; 3 ) types of products; 4) product materials and preparatory manufacturing process; and 5) workers. ${ }^{23}$

Following the above research, the Ministry of Agriculture and Commerce published the report entitled "Habutae kojo ni okeru seisan noritsu oyobi sonshitsu jikan ni kansuru chosa" (Research concerning productivity and time loss at Habutae silk factories) (February 1924). ${ }^{24}$ The research covered five main questions ${ }^{25}$ at silkweaving factories in Fukui City. In the summary, the report emphasized the importance of "always reminding factory owners of the need to take a scientific approach to time loss" and "to unify and simplify work methods." 26 To the managers of weaving factories, the report also expounded the virtue of scientific shop management, claiming 


\section{Table 1 Productivity in Major Textiles (1920)}

\begin{tabular}{|c|c|c|c|c|c|c|c|c|c|c|c|c|c|c|c|}
\hline \multirow[b]{2}{*}{ Textiles } & \multicolumn{3}{|c|}{ Operation Time } & \multicolumn{3}{|c|}{ Efficiency } & \multicolumn{3}{|c|}{$\begin{array}{l}\text { Production per Hour } \\
\text { per Machine }\end{array}$} & \multicolumn{3}{|c|}{$\begin{array}{l}\text { Production per Hour } \\
\text { per Worker }\end{array}$} & \multicolumn{3}{|c|}{$\begin{array}{c}\text { Production } \\
\text { per Wage }=\neq 1\end{array}$} \\
\hline & High & Low & Ave. & High & Low & Ave. & High & Low & Ave. & High & Low & Ave. & tigh & Low & Ave. \\
\hline trir & nix & 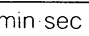 & ec & & $\%$ & $\%$ & - & 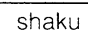 & $\mathrm{ku}$ & shaku & 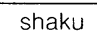 & $u$ & $u$ & $u$ & ku \\
\hline Miviainet & & 34.12 & 51 & 98.10 & 33.00 & 72.07 & 14.90 & 6.2 & 10.39 & 60.297 & 5.1 & 25.748 & 297.98 & & 171.30 \\
\hline Vhite Cotton & 59.07 & 45.42 & 56.15 & 95.60 & 80.30 & 90.60 & $\begin{array}{l}\text { sun } \\
229\end{array}$ & $\begin{array}{l}\text { sun } \\
127\end{array}$ & $\begin{array}{r}\text { sun } \\
172.7\end{array}$ & $\begin{array}{r}\text { sun } \\
1,027\end{array}$ & $\begin{array}{l}\text { sun } \\
580\end{array}$ & $\begin{array}{r}\text { sun } \\
767.7\end{array}$ & $\begin{array}{l}\text { shaku } \\
3,505\end{array}$ & $\begin{array}{r}\text { haku } \\
813\end{array}$ & $\begin{array}{r}\text { sun } \\
2,050\end{array}$ \\
\hline labutae for Export & 58.14 & 15.36 & 48.55 & 93.00 & 26.00 & 76.90 & & $\begin{array}{r}\text { sun } \\
10.5\end{array}$ & $\begin{array}{r}\text { sun } \\
37.4\end{array}$ & $\begin{array}{r}\text { sun } \\
132.6\end{array}$ & $\begin{array}{r}\text { sun } \\
36.3\end{array}$ & $\begin{array}{r}\text { sun } \\
65.3\end{array}$ & $\begin{array}{r}\text { sun } \\
1350.1\end{array}$ & $\begin{array}{l}\text { sun } \\
290\end{array}$ & $\begin{array}{r}\text { sun } \\
607.2\end{array}$ \\
\hline repe & 58.00 & ח & 5400 & 81.60 & 0 & 70.80 & & $\begin{array}{r}\text { bu } \\
768\end{array}$ & $\begin{array}{r}\text { bu } \\
973\end{array}$ & $\begin{array}{r}\text { bu } \\
1,259\end{array}$ & $\begin{array}{r}\text { bu } \\
600\end{array}$ & $\begin{array}{r}\text { bu } \\
892\end{array}$ & $\begin{array}{r}\text { bu } \\
1,280\end{array}$ & $\begin{array}{r}\text { bu } \\
673\end{array}$ & $\begin{array}{r}\text { bu } \\
871\end{array}$ \\
\hline $\begin{array}{l}\text { tripe Cotton } \\
\text { or Export }\end{array}$ & 6.38 & 34.01 & 51.37 & 83.50 & 56.70 & 72.157 & $\begin{array}{r}\text { yard } \\
7.635\end{array}$ & $\begin{array}{r}\text { yard } \\
2.273\end{array}$ & $\begin{array}{r}\text { yard } \\
3.662\end{array}$ & $\begin{array}{r}\text { yard } \\
15.27\end{array}$ & $\begin{array}{l}\text { yard } \\
2.89\end{array}$ & $\begin{array}{l}\text { yard } \\
6.71\end{array}$ & $\begin{array}{r}\text { yard } \\
52.955\end{array}$ & $\begin{array}{l}\text { yard } \\
23.5\end{array}$ & $\begin{array}{r}\text { yard } \\
36.423\end{array}$ \\
\hline Silk Crepe for Export & 50.16 & 23.24 & 37.07 & 84.10 & 39.00 & 60.97 & $\begin{array}{r}\text { bu } \\
485\end{array}$ & $\begin{array}{r}\text { bu } \\
210\end{array}$ & $\begin{array}{r}\text { bu } \\
307.2\end{array}$ & $\begin{array}{r}\text { bu } \\
820\end{array}$ & $\begin{array}{r}\text { bu } \\
126\end{array}$ & $\begin{array}{r}\text { bu } \\
369.1\end{array}$ & $\begin{array}{r}\text { bu } \\
7.646\end{array}$ & $\begin{array}{r}\text { bu } \\
1,446\end{array}$ & $\begin{array}{r}\text { bu } \\
3,400.9\end{array}$ \\
\hline Kais & 49.40 & & & 60 & 0 & 87.20 & $\begin{array}{r}\text { bu } \\
326\end{array}$ & $\begin{array}{r}\text { bu } \\
222\end{array}$ & $\begin{array}{r}\text { bu } \\
283.6\end{array}$ & $\begin{array}{r}\text { bu } \\
617\end{array}$ & $\begin{array}{r}\text { bu } \\
272\end{array}$ & $\begin{array}{r}\text { bu } \\
464.4\end{array}$ & $\begin{array}{r}\text { bu } \\
807\end{array}$ & $\begin{array}{r}\text { bu } \\
429\end{array}$ & $\begin{array}{r}\text { bu } \\
607.4\end{array}$ \\
\hline $\begin{array}{l}\text { Or } \\
\text { larket }\end{array}$ & 448 & 41.15 & 48.07 & 89.40 & 64.00 & 78.60 & $\begin{array}{r}\text { bu } \\
835\end{array}$ & $\begin{array}{r}\text { bu } \\
644.9\end{array}$ & $\begin{array}{r}\text { bu } \\
746.8\end{array}$ & $\begin{array}{r}\text { bu } \\
411\end{array}$ & $\begin{array}{r}\text { bu } \\
225\end{array}$ & $\begin{array}{r}\text { bu } \\
3101.1\end{array}$ & $\begin{array}{r}\text { bu } \\
3,318\end{array}$ & $\begin{array}{r}\text { bu } \\
1,726\end{array}$ & $\begin{array}{r}\text { bu } \\
2,657.0\end{array}$ \\
\hline Cotton Kokura Cloth & 55.48 & 33.08 & 46.51 & 68.38 & 39.00 & 56.60 & $\begin{array}{r}\text { bu } \\
929\end{array}$ & $\begin{array}{r}\text { bu } \\
440\end{array}$ & $\begin{array}{r}\text { bu } \\
663.7\end{array}$ & $\begin{array}{r}\text { bu } \\
1.502\end{array}$ & $\begin{array}{r}\text { bu } \\
1,220\end{array}$ & $\begin{array}{r}\text { bu } \\
804\end{array}$ & $\begin{array}{r}\text { bu } \\
9.900\end{array}$ & $\begin{array}{r}\text { bu } \\
3.200\end{array}$ & $\begin{array}{r}\text { bu } \\
5,735.7\end{array}$ \\
\hline Silk Satin for Export & 54.43 & 43.26 & 47.56 & 80.00 & 61.70 & 73.90 & $\begin{array}{r}\text { bu } \\
329\end{array}$ & $\begin{array}{r}\text { bu } \\
200\end{array}$ & $\begin{array}{l}\text { shaku } \\
271.0\end{array}$ & $\begin{array}{r}\text { bu } \\
987\end{array}$ & $\begin{array}{r}\text { bu } \\
480\end{array}$ & $\begin{array}{r}\text { bu } \\
633.7\end{array}$ & $\begin{array}{r}\text { shaku } \\
73.3\end{array}$ & $\begin{array}{r}\text { shaku } \\
31.6\end{array}$ & $\begin{array}{r}\text { shaku } \\
48.5\end{array}$ \\
\hline Bath Towels & 52.58 & 43.20 & 48.25 & 98.35 & 72.00 & 82.48 & $\begin{array}{r}\text { inch } \\
483.6\end{array}$ & $\begin{array}{l}\text { inch } \\
224\end{array}$ & $\begin{array}{r}\text { inch } \\
331.95\end{array}$ & $\begin{array}{r}\text { inch } \\
323.34\end{array}$ & $\begin{array}{r}\text { inch } \\
17.73\end{array}$ & $\begin{array}{r}\text { sun } \\
243.51\end{array}$ & $\begin{array}{c}\text { inch } \\
3352.31\end{array}$ & $\begin{array}{r}\text { inch } \\
838.34\end{array}$ & $\begin{array}{r}\text { inch } \\
2,690.6\end{array}$ \\
\hline Silk Pongee & 56.14 & 2 & 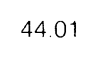 & .00 & 0 & 57.80 & $\begin{array}{r}\text { bu } \\
468\end{array}$ & $\begin{array}{r}\text { bu } \\
286\end{array}$ & $\begin{array}{r}\text { bu } \\
369.4\end{array}$ & $\begin{array}{r}\text { bu } \\
904\end{array}$ & $\begin{array}{r}\text { bu } \\
298\end{array}$ & $\begin{array}{r}\text { bu } \\
461.4\end{array}$ & $\begin{array}{r}\text { sun } \\
727.8\end{array}$ & $\begin{array}{l}\text { sun } \\
198\end{array}$ & $\begin{array}{r}\text { sun } \\
408.3\end{array}$ \\
\hline Cotton Flannel & 57.19 & 33.04 & 49.35 & 76.00 & 45.00 & 63.90 & & $\begin{array}{l}\text { yard } \\
2.43\end{array}$ & $\begin{array}{l}\text { yard } \\
3.76\end{array}$ & $\begin{array}{r}\text { yard } \\
12.57\end{array}$ & $\begin{array}{l}\text { yard } \\
3.17\end{array}$ & $\begin{array}{l}\text { yard } \\
6.56\end{array}$ & $\begin{array}{r}\text { yard } \\
82.84\end{array}$ & $\begin{array}{l}\text { yard } \\
16.2\end{array}$ & $\begin{array}{r}\text { yard } \\
37.94\end{array}$ \\
\hline
\end{tabular}

Nōshōmushō Kōmukyoku, "Shuyō Orimono." p. 4. This report does not indicate the method of calculation used to produce this table. According to the later productivity research. however, productivity in the textile industry was computed as follows:

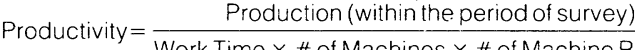


that "research on efficiency based on production per hour or day is the welcome means to advance scientifically the method of management in our industry." 27 It is noteworthy that the term "scientific management" came to be used at this time instead of "improving factory productivity."

The other remarkable research was "Kakushu orimono kojo ni okeru seisan noritsu chosa" (Research on productivity at various weaving factories) by the Factory Bureau of the Ministry of Agriculture and Commerce for one month from the middle of February $1926 .{ }^{28}$ In the summary of the research report entitled "Kojo kanri ni kansuru jiko" (Section on factory management) is found the following citation: "Various factories practice scientific management, and many of them have achieved good results in increasing productivity. Regrettably, however, among the factories investigated this time were those that not only had failed to study management scientifically but also decreased productivity because of shortcomings in management."29

The summary of the report suggests that the "various factories" in the machine and spinning industries incorporated scientific management by the mid-1920s as well as that, to some extent, the government recognized the need for a scientific method of management. Needless to say, textile factories, especially medium and small ones, were unable to achieve much of scientific management even at this time. For machine maintenance, for example, while large factories employed full-time specialists, medium and small plants let foremen maintain machines. At medium and small factories that constantly faced excessive competition, scientific management remained a remote possibility.

In short, the government policies to introduce scientific management into textile plants were not successful in that they could not convince wide-ranging factory owners of scientific management. The failure had a significant impact on the later movement to rationalize industry. That movement, which took place in the 1930s, ignored from the beginning the idea of rationalization through scientific management in the textile industry. Instead, it exclusively emphasized rationalization through government control over industry. The movement's predisposition no doubt was related to the failure of the government's earlier attempt to introduce scientific management into the textile industry.

Along with research on production efficiency in the textile industry, the government started formulating policies on standardization, which was indispensable for scientific management. In April 1921, it 
created the Kogyohin Kikaku Toitsu Chosakai (Research Committee on Standardization of Industrial Products), the standing committee presided over by the Minister of Agriculture and Commerce. The committee worked toward the Japanese Engineering Standard, dividing research areas into four categories. ${ }^{30}$ At the second plenary session held in 1922, the committee decided to act in concert with similar research organizations in the West. Consequently, it exchanged information with organizations that promoted standardization in twenty countries, including Great Britain (British Engineering Standard), America (American Engineering Standard), and Germany (Normenausschuss der Deutschen Industrie). In 1929, furthermore, Japan joined the International Federation of the National Standardizing Associations. ${ }^{31}$

Although the government policies to introduce scientific management into textile industry failed, the policies toward standardizing products were a success to the degree that they created a basis for the Japanese Engineering Standard and encouraged Japan's participation in the international standardizing movement.

The Research Committee on Standardizing was incorporated into the Provisional Industrial Rationalization Bureau at its founding in June 1930 , thereby becoming a part of the movement led by the government and business associations.

The foregoing analysis confirms that the government became interested in scientific management while preparing for enforcement of the Factory Law, and that in the 1920s it clearly recognized the importance of scientific management for productivity. To foster a full-fledged movement for scientific management, however, the government needed the cooperation of business associations.

\section{Scientific Management and Business Associations}

Japanese business associations, unlike the government, could recognize the importance of scientific management only through international exchanges in the 1920s.

\section{(1) Businessmen's Visit to America and England}

The leaders of Japanese business associations came to have a better understanding of scientific management when a party consisting mostly of the members of the Japanese Industrial Club traveled to America and England from October 1921 to May 1922. The purpose of the trip was to inspect the postwar economy and industry of the 
two countries. Before its departure, the businessmen's party chose five areas of study, one of which, designated as the industry (general policies) section, included items germane to scientific management, such as "Kojo soshiki oyobi keiei no shinkenkyu" (New research on factory organization and management.) ${ }^{32}$ During the 45-day sojourn in the United States, the party visited 93 banks, companies, and factories. In England, where it stayed for 44 days, the party toured 63 banks, companies, and factories. ${ }^{33}$ The party was deeply impressed by scientific management, especially in the United States. Upon returning to Japan, at the dinner given in its honor, the businessmen's group presented an "opinion," targeting ten areas as urgently requiring improvement. ${ }^{34}$ The eighth area was called "Kojo Keiei no Kenkyu" (Research on factory management), which corresponded to "New Research on Factory Organization and Management" mentioned above. The following excerpt illustrates the point.

"Research on Factory Management.": On the point of factory management, our country falls far behind foreign countries. Moreover, in countries like the United States, efforts have been expended for some time now on scientific research into the method of production increment as well as economical management of all aspects of the factory, including its organization. These efforts to tap the potentials of mass production are indeed proving remarkably effective. Thus the disparity in production capacity between that country and ours threatens to widen ever greater. We can no longer pride ourselves on cheap labor but must apply ourselves diligently to this type of research as a part of the state's industrial policy. Hereafter, both the government and private sector should not spare any resources to create various research organizations or expand existing ones. The idea is to bridge research over to industry to make use of progress in research for purposes of industrial development. ${ }^{35}$

The above proposal illuminates how the Japanese businessmen's mission to England and America affected the business leaders' perception and evaluation of scientific management. The mission thought that "modern" and "scientific" factory management meant a combination of the Taylor and Ford systems. Ford's mass production system consisting of conveyer assembly lines was well-known in the United States. The Japanese business group witnessed the Taylor and Ford systems combined together rather than the twenty-year evolution of modern scientific factory management from the Taylor to Ford system. 
It is no wonder that the group felt the huge "discrepancy between America and Japan." This is why it advocated research on scientific factory management by the joint effort of "the government and private sector to create various research organizations..., to bridge research over to industry."

Through the businessmen's mission to England and America, especially the latter, Japanese business associations came to recognize the importance of cooperating with the government and academic world. Their new outlook was manifest in their subsequent effort to learn from the experience of advanced countries at international conferences focused on scientific management and rationalization of industry.

\section{(2) Participation in International Conferences}

So far little is known as to how international conferences addressed the issues relating to rationalization of industry and scientific management in the 1920s. In the following, therefore, I will discuss in some detail how the two international conferences attended by Japanese business representatives treated rationalization and scientific management.

The first international conference that Japanese business associations joined was the Second International Scientific Management Conference in Brussels, Belgium, in 1925. Prior to that conference, the International Chambers of Commerce (ICC) located in Paris wrote a letter to the ICC's Japanese committee requesting that Japan send a delegation of both group and individual members to the Second International Scientific Management Conference. ${ }^{36}$ The Japanese committee, organized jointly by the Japanese Economic Federation and the Association of the Chambers of Commerce, sent to organizations and individuals a brief to invite the ICC's regular or associate members as well as the subscribers to its publications. The brief explained the ICC's letter and invited its recipients to attend the conference in Brussels. The committee received ten applications from organizations and individuals. The applicants included both the Japanese Industrial Club and the Japanese Economic Federation, which were the leading across-the-board business associations in Japan at the time. ${ }^{37}$

The purpose of the conference was to "lower industrial production cost through scientific management of labor and prevent labor disputes expected from wage cutting." To that end, the conference proposed to deliberate application of scientific management apart from political 
consideration" and "provide countries that have used scientific management with a forum to exchange their experiences." 38 Clearly, the relationship between the idea of "spiritual revolution" and scientific management on the one hand and labor dispute on the other was a weighty problem worldwide. The Brussels Conference aimed to overcome that problem by exchanging information on the experience of participating nations. It ideally suited the intent of the Japanese business associations that desired to learn from the expertise of the West. ${ }^{39}$

The first international conference on industrial rationalization that the government, business circles and academic world attended together was the Geneva International Economic Conference held two years after the Brussels Conference. It drew 194 participants from 50 countries. The participants came from various professional fields: politicians, businessmen, scholars, and others. All but the Japanese attended as individuals, not as "the plenipotentiaries" of their respective governments. In Japan's case, 17 delegates were selected by the government to represent the government, business world, and academic community. ${ }^{40}$

Before the delegation left for the conference, Koseikai (the Industrial Policy Association) held a meeting attended by the delegates. At the meeting, Chuzaburo Shiba, a Ph.D. in engineering, commented that "the various ministries of the government have made their information available to the delegates, who are getting together every day to discuss these materials." 41 Shiba's comment suggests that the experts from the government, business world, and research community collaborated with each other for the forthcoming conference.

The central issues of the Geneva Conference were trade barriers and tariff reductions. But the conference was important as the first international forum that defined "rationalization" and agreed upon publicizing scientific management. It called rationalization "the technical and organizational method designed to minimize waste of both labor and resources." It further stated: "Rationalization includes scientific management of labor, standardization of materials and products, simplification of production process, and improvement of transportation and distribution." 42 It also unanimously resolved that "recognizing the usefulness of rationalization and scientific management," the member nations "direct their endeavors in this area harmoniously on a grand and far-reaching scale." ${ }^{43}$ Upon returning to Japan, Tetsujiro Shidachi, one of Japan's delegates and the president of the Industrial Bank of Japan, recommended that business associ- 
ations such as the Japanese Economic Federation urge the government to implement the resolution of the conference. ${ }^{44}$

Understanding of scientific management deepened in the 1920s both inside the government and among private enterprises, and the need to adopt it became recognized through international conferences. It should be mentioned, however, that changes, too, occurred at this time in the scope of research. In the resolution of the Geneva Economic Conference, "scientific management" not only meant "rationalization" at factories represented by time-motion study, but also included wider areas, such as selling and distributing sections. This conception of scientific management reflected the influence of the German-type industrial rationalization developed after World War I.

As mentioned above, Japanese business leaders in the early 1920s were interested in modern scientific plant management known as the Taylor and Ford System. In the late 1920s, however, the business world learned the more extended meaning of scientific management by participating in international conferences. Necessarily, the business leaders looked favorably toward the German-type industrial rationalization movement.

\section{Joint Scientific Management Movement of the Government and the Business Community}

By the end of the 1920s, collaboration between the government and the business community was established sufficiently well to give rise to a well-integrated scientific management movement in the 1930s. The government's position on collaboration crystallized during the deliberative sessions of the Ad Hoc Industrial Council, which created the Provisional Industrial Rationalization Bureau. The business community accepted cooperation with the government while preparing for the Tokyo World Engineering Congress. No previous work has touched on the content of the Tokyo World Engineering Congress or assessed its significance. In the following, therefore, I will first analyze that conference and explain its meaning, and then present profiles of the individuals who were at the center of the joint scientific management movement of the government and business.

\section{(1) The Tokyo World Engineering Congress}

The Tokyo World Engineering Congress was held in Tokyo for 10 days from October 29 to November 7, 1929, following the collapse of the Wall Street stock market. Participating countries numbered 42, 
and foreign participants 985 , of which 314 submitted papers without attending the conference. The purpose of the Conference was to promote "cooperation among the engineers, industrialists, and related personnel of the countries of the world," encourage "presentation of articles on engineering and industry," and facilitate "exchange of opinions in these regards so as to increase knowledge as well as cultivate friendly relations among experts." It was also declared that the Conference "will publish opinions and resolutions for use worldwide." 45

The history of the Tokyo World Engineering Congress goes back to the telegram sent in March 1925 by E.A. Sperry of the American Mechanical Association to Masao Kamo of the Japanese Engineering Association. ${ }^{46}$ The latter association immediately applied for government approval and support for an international industrial conference. After referring the matter to the Japanese Industrial Club in May 1925 , the government, with the consent of the Club, communicated to the board of the Engineering Club and the leaders of the academic and business communities in October 1926 that it would approve and support such a conference. ${ }^{47}$

The government, which had already begun to work in conjunction with the business community to prepare for the Geneva Economic Conference, made the personnel in the Ministries of Commerce and Industry and Railways available to the Tokyo World Engineering Congress. The Japanese Industrial Club cooperated with the Japanese Economic Federation in providing the preparatory committee of the conference with offices and office personnel as well as in raising funds in the private sector. In the academic world, the 12 bodies $^{48}$ under the Engineering Association called for papers for the conference. Thus while preparing for the Tokyo World Engineering Congress, ${ }^{49}$ the government, business associations, and academic community became allied to each other.

Table 2 shows the number of papers read at the conference. The total was 813 . The most numerous at 124 were the papers for the 11 th Division - the mining and metallurgy division - and the smallest at 10 were those for the 12 th Division.

The Scientific Management Division met for four days following the schedule shown in Table 3 . This division was chaired mostly by F. Mauro, Professor of the Milan Institute of Technology and the Director of both the Rome Institute of Scientific Management and the Geneva International Institute of Management. Serving also as chairmen were L. Gilbreth, the wife of F. Gilbreth, and J.W. Roe, 
Table 2 Number of Papers Presented at the World Engineering Congress

\begin{tabular}{|c|c|c|c|c|c|c|c|c|c|c|c|c|}
\hline & \multirow[b]{2}{*}{ Area of Specialization } & \multirow[b]{2}{*}{ U.S.A. } & \multicolumn{8}{|c|}{ Name of Country } & \multirow[b]{2}{*}{$\begin{array}{l}\text { Total by } \\
\text { Special- } \\
\text { ization }\end{array}$} & \multirow[b]{2}{*}{$\begin{array}{l}\text { Total by } \\
\text { Division }\end{array}$} \\
\hline & & & England & France & Germany & Italy & China & USSR & Japan & $\begin{array}{l}\text { Others } \\
(14)\end{array}$ & & \\
\hline Div. 1 & $\begin{array}{l}\text { (1) Industry in General } \\
\text { (23) Miscellaneous }\end{array}$ & 6 & $\underline{3}$ & $\begin{array}{r}1 \\
-\end{array}$ & $\begin{array}{r}1 \\
-\end{array}$ & $\begin{array}{l}9 \\
2\end{array}$ & - & - & $\begin{array}{r}10 \\
3\end{array}$ & 6 & $\begin{array}{r}36 \\
5\end{array}$ & 41 \\
\hline Div. 2 & $\begin{array}{l}\text { (2) Industrial Science } \\
\text { (3) Precision Machinery } \\
\text { (16) Aviation } \\
\text { (21) Industrial Material }\end{array}$ & $\begin{array}{l}4 \\
1 \\
1 \\
2\end{array}$ & $\begin{array}{l}4 \\
6 \\
3\end{array}$ & $\frac{3}{1}$ & $\frac{-}{-}$ & $\begin{array}{r}4 \\
- \\
1 \\
-\end{array}$ & $\begin{array}{c}2 \\
- \\
-\end{array}$ & $\begin{array}{r}- \\
1 \\
1\end{array}$ & $\begin{array}{r}18 \\
11 \\
9 \\
7\end{array}$ & $\begin{array}{l}3 \\
- \\
-\end{array}$ & $\begin{array}{l}38 \\
12 \\
22 \\
15\end{array}$ & 87 \\
\hline Div. 3 & $\begin{array}{l}\text { (4) Architectural and } \\
\text { Structural Engineering }\end{array}$ & 7 & 2 & 1 & 6 & 5 & 2 & - & 24 & 4 & 51 & 51 \\
\hline Div. 4 & (5) Construction & 9 & 5 & 2 & 6 & 6 & 3 & 3 & 23 & 16 & 73 & 73 \\
\hline Div. 5 & $\begin{array}{l}\text { (6) Railways } \\
\text { (7) Transportation }\end{array}$ & $\begin{array}{l}8 \\
3\end{array}$ & $\begin{array}{l}6 \\
5\end{array}$ & - & 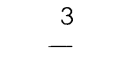 & $\begin{array}{r}47 \\
1\end{array}$ & $\begin{array}{r}4 \\
-\end{array}$ & - & 20 & - & $\begin{array}{r}96 \\
9\end{array}$ & 105 \\
\hline Div. 6 & (8) Communication & 4 & 4 & 2 & 11 & 1 & 2 & 1 & 24 & 3 & 52 & 52 \\
\hline Div. 7 & $\begin{array}{l}\text { (9) Power } \\
\text { (10) Electrical Engineering } \\
\text { (11) Illumination }\end{array}$ & $\begin{array}{l}6 \\
6 \\
1\end{array}$ & $\begin{array}{l}5 \\
2 \\
2\end{array}$ & $\begin{array}{r}1 \\
-\end{array}$ & $\frac{1}{1}$ & $\begin{array}{r}1 \\
2 \\
-\end{array}$ & $\frac{-}{2}$ & $\frac{1}{-}$ & $\begin{array}{r}7 \\
25 \\
14\end{array}$ & $\begin{array}{r}5 \\
9 \\
-\end{array}$ & $\begin{array}{l}27 \\
46 \\
18\end{array}$ & 91 \\
\hline Div. 8 & $\begin{array}{l}\text { (12) Mechanical Engineering } \\
\text { (13) Freezing } \\
\text { (14) Spinning \& Weaving } \\
\text { (17) Automobile }\end{array}$ & $\begin{array}{r}7 \\
-2 \\
-3\end{array}$ & $\frac{8}{-}$ & $\frac{1}{1}$ & $\begin{array}{l}2 \\
- \\
-\end{array}$ & $\begin{array}{r}2 \\
1 \\
- \\
-\end{array}$ & $\frac{1}{-}$ & $\begin{array}{l}- \\
- \\
-\end{array}$ & $\begin{array}{r}30 \\
1 \\
5 \\
2\end{array}$ & $\begin{array}{r}4 \\
1 \\
- \\
-\end{array}$ & $\begin{array}{r}55 \\
5 \\
6 \\
8\end{array}$ & 74 \\
\hline Div. 9 & $\begin{array}{l}\text { (15) Shipping \& Marine } \\
\text { Machinery }\end{array}$ & 7 & 6 & 2 & - & 1 & - & - & 17 & 1 & 34 & 34 \\
\hline Div. 10 & $\begin{array}{l}\text { (18) Chemical Industry } \\
\text { (19) Fuel \& Combustion }\end{array}$ & $\begin{array}{l}4 \\
2\end{array}$ & $\begin{array}{l}3 \\
8\end{array}$ & $\begin{array}{l}5 \\
1\end{array}$ & -3 & 2 & - & $\begin{array}{r}1 \\
-\end{array}$ & $\begin{array}{r}30 \\
9\end{array}$ & $\begin{array}{l}3 \\
-\end{array}$ & $\begin{array}{l}51 \\
20\end{array}$ & 71 \\
\hline Div. 11 & (20) Mining \& Metallurgy & 14 & 6 & 4 & 14 & 1 & 2 & - & 77 & 6 & 124 & 124 \\
\hline Div. 12 & (22) Scientific Management & 2 & - & - & 1 & 2 & - & - & 5 & 一 & 10 & 10 \\
\hline Total & & 99 & 81 & 26 & 53 & 88 & 18 & 8 & 371 & 69 & 813 & 813 \\
\hline
\end{tabular}

\&

Based on Nihon Kogyo Kurabu, "Bankoku Kogyo Kaigi", p. 63 


\section{Table 3 Schedule of the Scientific Management Division of the World Engineering Congress}

Date

Oct. 30, A. M.

Oct. 31, A. M.

Nov. 1, A. M.

Nov. 4, A. M.
Chair

Number of Papers

F. Mauro (Italy)

L. M. Gilbreth (U.S.A.)

2

F. Mauro (Italy)

3

F. Mauro (Italy)

3

Nihon Kōgyō Kurabu, "Bankoku Kōgyō Kaigi", p. 61

Table 4 Papers Submitted to the Scientific Management Division of the International Industrial Conference

\begin{tabular}{|c|c|c|}
\hline Author & Title & Pages \\
\hline $\begin{array}{l}\text { L.P. Alford } \\
\text { (U.S.A.) }\end{array}$ & Scientific Industrial Management & 14 \\
\hline $\begin{array}{l}\text { J. H. Van Derventer } \\
\text { (U.S.A.) }\end{array}$ & $\begin{array}{l}\text { Development and Trends in Standardized Quality } \\
\text { Production }\end{array}$ & 16 \\
\hline $\begin{array}{l}\text { F. Mauro } \\
\qquad(\text { ITALY) }\end{array}$ & The Movement for Rationalization in Europe & 11 \\
\hline $\begin{array}{l}\text { L. Palma } \\
\qquad(\text { ITALY) }\end{array}$ & $\begin{array}{l}\text { Theoretical and Practical Aspects of Scientific Organization } \\
\text { of Industrial Work }\end{array}$ & 11 \\
\hline $\begin{array}{l}\text { T. Godo } \\
\text { (JAPAN) }\end{array}$ & $\begin{array}{l}\text { On Some Experiences in Scientific Management of } \\
\text { Machine shops }\end{array}$ & 6 \\
\hline $\begin{array}{l}\text { K Takahashi } \\
\text { (JAPAN) }\end{array}$ & $\begin{array}{l}\text { Proper Duration of Rest Determined by Change of Oxygen } \\
\text { Requirement after Cessation of Work }\end{array}$ & 26 \\
\hline $\begin{array}{l}\text { K. Takahashi } \\
\text { (JAPAN) }\end{array}$ & $\begin{array}{l}\text { Study regarding the Proper Time for Meals as Determined } \\
\text { by the Work Change of Oxygen Requirement in the Course } \\
\text { Working Hours }\end{array}$ & 24 \\
\hline $\begin{array}{l}\text { K. Takahashi } \\
\text { (JAPAN) }\end{array}$ & $\begin{array}{l}\text { Apportionment of Wages for Rivet Workers Determined } \\
\text { from the Oxygen Requirement }\end{array}$ & 59 \\
\hline $\begin{array}{l}\text { B. Petermann } \\
\text { (GERMANY) }\end{array}$ & $\begin{array}{l}\text { Modern Research in General Psychology and Its } \\
\text { Consequences for Industrial Psychology }\end{array}$ & 2 \\
\hline $\begin{array}{l}\text { H. Takamine } \\
\text { (JAPAN) }\end{array}$ & $\begin{array}{l}\text { An Index Comparison Method for the Diagnosis of the Mental } \\
\text { Qualities of Inefficient Personnel, as well as by Traumatic } \\
\text { Neurosis, Neurasthenia and the Other Mental Diseases }\end{array}$ & 14 \\
\hline
\end{tabular}

Source: Proceedings of the World Engineering Congress Vol. XXXVIII (Scientific Management Section XII of Congress), World Engineering Congress, 1931. 
Professor of New York University.

The titles of the papers presented before the Scientific Management Division are shown in Table 4. The Japanese participants prepared five papers. Takuo Godo, who had introduced scientific management at the Kure Naval Dockyard, read a paper on division between production process and planning, on the one hand, and comparison between planning and results on the other. His paper was based on ten years of field experience. Kotaro Takahashi, the part-time employee of the Ministry of Commerce and Industry who researched the area of industrial hygiene and had published, among others, "Kojo jin'ai no sagyosha ni oyobosu eikyo" (Dust at factories and its effect on workers' health), presented three papers, one on the relationship between oxygen consumption and break time, another on the relationship between oxygen consumption and meal time, and the third on wage distribution among rivet operators. Hiroshi Takamine reported on worker's mental health based on rich empirical data.

Although the submissions to the Scientific Management Division were not numerous, experts from America and Europe participated to generate lively discussions. Those who, like F. Mauro, upheld the "convergence theory" argued that the American methods of industrial rationalization and scientific management could not be applied to other countries, while J.W. Roe and others supported the nonconvergence theory that the principles of scientific management were applicable at any factory, regardless of nationality. ${ }^{50}$ The conflict between the two views became the chief issue in the participants' lectures even outside the conference halls. ${ }^{51}$ Nevertheless, the 12th Division adopted the resolution that education on scientific management be enriched and widespread. ${ }^{52}$

The Tokyo World Engineering Congress thus provided the Japanese with the opportunity not only to "further friendly exchange" with foreign experts but also to "advertise abroad the state of Japanese industry, glimpse the height of the industrial standards of developed countries, and absorb their expertise." 53 On matters of scientific management, too, the conference provided a similar opportunity. Unwittingly, moreover, the "tripartite participation" by the government, business associations, and academic field prepared them to cooperate with each other in adopting various rationalization policies of the world on the eve of Japan's lifting of the gold embargo.

In short, the Tokyo World Engineering Congress played a crucial role in creating the scientific management movement that partook of the industrial rationalization movement initiated by the government. 


\section{(2) The Committee on Production Management}

The nucleus of the scientific management movement originated by the government and business firms was the Committee on Production Management of the Provisional Industrial Rationalization Bureau created in June 1930 as an extra-ministerial organ of the Ministry of Commerce and Industry. The Bureau had as advisers and chairmen of various committees the leading members of the Japanese business world. This organizational structure indicated that cooperation between the government and business was solid.

Noteworthy was the fact that the Committee on Production Management contained all of the individuals responsible for introducing scientific management into Japan. The chairman was Okiie Yamashita, who used scientific management at the National Railways' repair plants. Among the committee members were Takuo Godo and Koichi Hidaka of the Kure Naval Dockyard. From the private sector came four men trained in America, namely, Shigeo Kato of the Niigata Ironworks, Toshisuke Takeo of the Karatsu Ironworks, Takeo Kato of Mitsubishi Electric and Nobuo Noda of the Mitsubishi Goshi (Limited Partnership). The greatest number of the committee members was drawn from the experts of the machine industry. From the textile industry came Gito Teruoka of the Kurashiki Labor Research Institute, who was known for his work in labor science. Enlisted also were Nissan's Yoshisuke Ayukawa and Sumitomo's Kiichi Mimura (at the Besshi Copper Mine), who were influential in the business community. Other notable figures were: Enjiro Awaji of Tokyo Imperial University, Yaekichi Sekiguchi of the Tokyo Institute of Technology, Toichiro Araki of the Araki Management Institute, and Hiroshi Takamine of the Takamine Institute of Individual Efficiency. Demonstrably, the scientific management movement of the government and business started by absorbing their expertise in various industries.

The Production Management Committee investigated and deliberated thirty topics concerning scientific management. The results were submitted in the form of "proposal booklets" to the Minister of Commerce and Industry, who was the head of the Rationalization Bureau. To implement these proposals, the Nihon Kogyo Kyokai (Japanese Industrial Association) was founded in May 1931, with Kumakichi Nakajima serving as president. The association accepted the membership of the factory discussion groups which had been organized to assist enforcing the Factory Law at the prefectural level. Selected on the basis of "one per prefecture," the discussion groups, numbering 
19 in November $1931,{ }^{54}$ became the network for the scientific management movement supported by the government.

The activities of the Japanese Industrial Association were twofold: spreading knowledge regarding production management and counseling factories. For the former genre of activity, the Association assisted study meetings of prefectural industrial associations. It sponsored lectures and seminars by university professors as well as experts working at innovative private enterprises or state-owned factories such as those under the ministries of the Army, Navy, and Railways. The Association also distributed publications of the Production Management Committee and the Financial Management Committee of the Provisional Industrial Rationalization Bureau. ${ }^{55}$ In the area of factory counseling, the Industrial Association offered long-term as well as short-term counseling services and gave seminars on job efficiency. ${ }^{56}$

The proposals of the Production Management Committee abundantly reflected the committee members' field experience. Most frequently cited were the experiences at the National Railways. In other words, the propelling force of the Japanese Industrial Association, which conveyed these proposals nationwide, consisted of engineers formerly employed by the Ministry of Railways. Both in terms of personnel and experience, the National Railways clearly set the standard of scientific management in Japan.

In the 1930s, then, manuals became available in the form of government publications containing proposals based on precedents that "proved first-hand the manifest effectiveness" 57 of scientific management. These manuals supported the scientific management movement of the government in cooperating with top leaders of the business community.

\section{Conclusion}

This article has discussed the history of the adoption and dissemination of scientific management by the government and business associations in the 1920 s and the early 1930s. The high points of my findings are as follows:

First, the government became interested in scientific factory management about the time that the Factory Law went into effect. It recognized the importance of scientific management in the 1920 s as it conducted research studies into production efficiency and implemented policies on product standardization in the textile industry. 
The research studies and policies of the Ministry of Agriculture and Commerce in turn became the origin of the scientific management movement by the government, a movement that gathered full force in the 1930s. The beneficial effects of scientific management accumulated at state-owned factories, such as the National Railways and the Kure Naval Dockyard, contributed much to the movement of the 1930s.

Second, the business associations were awakened to scientific management in the 1920s through the businessmen's trip to America and England. The business community's knowledge deepened through international exchanges such as the Second International Scientific Management Conference and the Geneva World Economic Conference.

Third, the scientific management movement of the 1930s had as its basis the collaboration among the government, business world, and academic community forged by the Tokyo World Engineering Congress. The scientific management movement in this context was a part of the industrial rationalization movement, with the cooperation of government and the private sector. The Production Management Committee, which pressed for scientific management, gathered the individuals responsible for introducing scientific management at both government and private enterprises. These individuals made best use of their knowledge for their publications.

Scientific management by the government, strongly influenced by the industrial rationalization of Germany, completely subsumed the similar movement in the private sector from the end of the 1930s through the first half of the 1940s. It came gradually to participate in forming the wartime system to increase production.

\section{Notes}

1. Juichi Nakase, "Kagakuteki kanriho donyu no Nihonteki tokushitsu" (Introduction of scientific management into Japan - its characteristics), in Toshikazu Imai and Takanobu Yamashita, ed., Gendai kigyo no kanri kozo (The Management Structure of Modern Industry), Tokyo: Mineruva Shobo, 1979; Toshiaki Chokki, "Kagakuteki kanriho no donyu" (Introduction of Scientific Management), in Keiichiro Nakagawa, ed., Nihon keieishi no kiso chishiki (The Basics of Business History in Japan), Tokyo: Yuhikaku 1974; Toshiaki Chokki, "Teira shisutemu no donyu" (Introduction of the Taylor System), in Yasuo Mishima and Shigeaki Yasuoka, ed., Nihon keieishi o manabu (Studies in 
Business History in Japan), Vol. II, Tokyo: Yuhikaku, 1976; Tetsuro Nakaoka, "Senchu sengo no kagakuteki kanri undo I: Nihon Noritsu Kyokai to Nikka Giren no katsudo ni sotte" (The Wartime and Postwar Scientific Management Movement I: In View of the Activities of the Japanese Management Association and the Union of Japanese Scientists and Engineers), Keizai zasshi (The Economics Journal), vol. 82, no. 1, 1981; Eisuke Daito, "Industrial Training and Factory Management in Japan, 1900-1930," presented at the Conference on Business History, Tokyo, March 20-22, 1981.

2. In this article, I will discuss mainly the Japanese Industrial Club and the Japanese Economic Federation, which, among all economic organizations, had a strong influence on the economic and industrial policies of the Japanese government.

3. Okiiye Yamashita, "On the Method of Rolling Stock Repair at the Japanese National Railways," Proceedings of the World Engineering Congress, vol. XVI, World Engineering Congress, 1981. Recently, Eisuke Daito has given a clear and detailed analysis of the same subject. See Eisuke Daito, "Industrial Training," pp. 11-16.

4. Koichiro Imano, "Kure Kaigun Kosyo ni miru kagakuteki kanri no aumi" (4) (Introduction of scientific management into Kure Naval Dockyard), in IE vol. 17, no. 9, Japanese Management Association, 1975, p. 91.

5. Takuo Godo, "On Some Experiments in Scientific Management of Machine Shops," Proceedings of the World Engineering Congress, vol. XXXVIII, 1931.

6. Nihon Denki Kabushiki Kaisha, ed., Nihon Denki Kabushiki Gaisha nanajunen shi (Seventy years of the Nihon Electric Company), Tokyo: Nihon Denki Kabushiki Kaisha, 1972, pp. 61-67.

7. Mitsubishi Denki Kabushiki Kaisha, ed., Kengyo kaiko (Remembrances of establishing enterprises), Tokyo: Mitsubishi Denki Kabushiki Kaisha, 1951, pp. 64-100, 339-343, 368-370.

8. Kabushiki Kaisha Niigata Tekkojo, ed., Niigata Tekkojo nanajunen shi (Seventy years of the Niigata Ironworks), Tokyo Kabushiki Kaisha Niigata Tekkojo, 1968, pp. 55-57, 170-171.

9. Shokichi Miyazaki, "Kosaku kikai o tsukutta hitobito sono 7: Takeo Toshisuke" (People who created industrial machines, series 7: Toshisuke Takeo), Kikai gijutsu (Industrial technology), vol. 29, no. 6, pp. 83-84.

10. Yasukawa Denki Seisakujo, ed., Yasukawa Denki no yonju nen 
(Forty years of Yasukawa Electric), Tokyo: Yasukawa Denki Seisakujo, 1965, pp. 2, 53-54.

11. Kabushiki Kaisha Ikegai Tekkojo, ed. Ikegai Tekkojo gojunen shi (Fifty Years of the Ikegai Ironworks), Tokyo: Kabushiki Kaisha Ikegai Tekkojo, 1931, pp. 15-18.

12. Kurashiki Boseki Kabushiki Kaisha, ed., Kaiko rokuju-go nen (Remembrances of sixty-five years). Tokyo: Kurashiki Boseki Kabushiki Kaisha, 1943, pp. 278-279.

13. Muto Sanji Zenshu Kankokai, ed., Muto Sanji Zenshu (Complete works of Sanji Muto), Vol. II. Tokyo: Shinjusha, 1964. p. 31: Romu Kanri Shiryo Hensankai, ed., Waga kuni romu kanri shi no ichi yoso: Kanebo ni okeru romu kanri no hensen (An aspect of labor management in Japan: History of labor management at Kanebo). Tokyo: Romu Kanri Shiryo Hensankai, 1970, pp. 53-60.

14. Toyo Boseki Kabushiki Kaisha, ed., Toyo Boseki nanaju nen shi (Seventy years of Toyo Boseki). Tokyo: Toyo Boseki Kabushiki Kaisha, 1953, pp. 179-201.

15. Nisshin Boseki Kabushiki Kaisha, ed., Nisshin Boseki rokuju nen shi (Sixty years of Nisshin Boseki). Tokyo: Nisshin Boseki Kabushiki Kaisha, 1959, pp. 361-369.

16. Beginning in 1920, Sanji Muto advocated "spiritual operation." It is not clear whether he had heard about F.W. Taylor's "spiritual revolution," but his ideas included the following: 1) Superiors inspire their subordinates by "spiritualizing" their own thoughts and deeds; 2) If "spiritualization" is complete, a noble "Kanebo temperament" will be born; 3) Supervision and control should be tempered; 4) Subordinates may report on superiors' "unspiritual conduct." Romu Kanri Shiryo Hensankai, Waga kuni romu, p. 55.

17. Noshomusho Komukyoku, ed., Shokogyo ni kansuru shisetsu (Commercial and industrial policies). Tokyo: Noshomusho, 1916, pp. 110-111.

18. Ibid., p. 11.

19. Concerning the number of trainees who went abroad, see the reports in Ibid., pp. 161-165. Arthur Shadwell, Industrial Efficiency: a comparative study of industrial life in England, Germany and America, London, 1913.

20. In 1919, Arthur Shadwell's Industrial Efficiency: a comparative study of industrial life in England, Germany and America, London, 1913, was translated by Umehiko Minakami, the part-time 
employee of the Ministry of Agriculture and Commerce, and published by Kokusai Jihosha as Obei kogyo noritsu: Ei Bei Doku kokuminsei to no kankei. K. Hathaway's article was also translated partly as "Kojo kanri ni tsuite" in Noshomusho Komukyoku, ed., Kogyo chosa iho, vol. I, no. 1 (1923), pp. 297-314.

21. Noshomusho Komukyoku, ed., Shuyo orimono no kogyo noritsu ni kansuru chosa (Research concerning industrial efficiency in representative textile production), 1921.

22. Ibid., p. 5.

23. Ibid., pp. 5-8.

24. Noshomusho Komukyoku, ed., "Habutae kojo ni okeru seisan noritsu oyobi sonshitsu jikan ni kansuru chosa" (Research concerning productivity and time loss at Habutae silk factories), Kogyo chosa iho, vol. V, no. 3 (1927).

25. The content of this research was: 1) productivity per hour and per day; 2) time loss; 3) relationship between temperature/humidity and work efficiency; 4) relationship between the change of light intensity and work efficiency; 5) workers' fatigue level.

26. Ibid., pp. 115-115.

27. Ibid., p. 116.

28. Shokosho Komukyoku Kogyoka, ed., "Kakushu orimono kojo ni okeru seisan noritsu chosa hokoku" (Research on productivity at various weaving factories), Kogyo chosa iho, vol. 5, no. 3 (1927).

29. Ibid., p. 19.

30. The research content was: Section, I, Metal materials; Section II, Non-metal materials; Section III, Electrical machines and instruments; Section IV, Other machines and instruments in general. See Eisuke Nagata, "Kogyohin kikaku toitsu jigyo no gaiyo" (Outline of policies to standardize industrial products), Kogyo chosa iho, vol I, no. 1 (1923), pp. 13-17. Nagata was an engineer and official of the Ministry of Agriculture and Commerce.

31. The International Federation of the National Standardizing Association was founded in 1928.

32. The research was divided into the following areas: 1) trading; 2) finance; 3) industry (general policies); 4) industry (special industries); 5) transportation. See: Nihon Kogyo Kurabu Ju-ichi Nen Kai, ed., Ei Bei homon jitsugyodan nisshi (Business groups's journal during its trip to England and America), 1926, pp. 20-26. Headed by Takuma Dan, the managing director of the Mitsui \& Company, the group was composed of 23 members, all of whom 
were leading figures in Japan's business world at that time. Among them was Yukinori Hoshino, who was the first Japanese translator of F.W. Taylor's works.

33. Ibid., p. 612.

34. The opinion contained the following ten sections: 1) Merger and rearrangement of business; 2) Improvement of the Chamber of Commerce; 3) Cultivation of business morality; 4) Strengthening of the Sino-Japanese relationship; 5) Promotion of vocational education; 6) Training of able personnel; 7) Service to public undertakings; 8) Study of factory management; 9) True meaning of "labor-management cooperation"; and 10) Repletion of communication network. (Ibid., pp. 582-590).

35. Ibid., pp. 588-589.

36. Nihon Keizai Rengokai, Dai yon kai hokoku (The fourth report). 1926, pp. 83-84; Nihon Kogyo Kurabu, Kaiho dai juichi go (Bulletin, no. 11), 1926, pp. 163-164.

37. The applicants were: Japanese Economic Federation, Japanese Industrial Club, Koseikai, Mitsui Mining Company, Association of the Imperial Railways, Zen'ichi Takiya, Nagoya Chamber of Commerce, Sumitomo Bank, Yokohama Industrial Association, and Chokuro Kadono of the Okura \& Co.

38. Nihon Kogyo Kurabu, Kaiho II, p. 163.

39. The conference was held from October 14 to 16, 1925. Eleven countries including Belgium, England, America and Italy attended. Addressed were the problems of applying scientific management to general affairs, production, sales, office work, public undertakings and agriculture. The participants' reports were published as "Congrès International de l'Organisation Scientifique du Travail." See Nihon Keizai Rengokai, Dai yon kai, p. 85.

40. Teijiro Ueda, Kokusai keizai kaigi to sono mondai (International conferences and their problems). Tokyo: Dobunkan, 1927, pp. 18-32. Kokusai Renmei Kyokai, ed., Kokusai keizai kaigi no giketsu (Resolutions of the International Economic Conference). Tokyo: Kokusai Renmei Kyokai, 1928, pp. 6-8.

41. Koseikai, ed., Kosei (Industrial policies). May 1926, p. 45.

42. Ibid.

43. Kokusai Rengo Kyokai, Kokusai keizai, pp. 118-119.

44. Nihon Keizai Rengokai \& Nihon Kogyo Kurabu, eds., Kokusai keizai kaigi sanretsu san daihyo shotai bansan sekijo sokkiroku (Stenographic record of the dinner given in honor of the three 
representatives who attended the International Economic Conference). 1927, p. 16.

45. Nihon Kogyo Kurabu nai Bankoku Kogyo Kaigi Jimusho, ed., Bankoku kogyo kaigi hokoku (Proceedings of the World Engineering Congress). Tokyo: Nihon Kogyo Kurabu nai Bankoku Kogyo Kaigi Jimusho, 1931, p. 29.

46. The telegram read: (Ibid. p. 1)

47. On May 22, 1925, the Chief of the Industrial Affairs Bureau of the Ministry of Commerce and Industry (the Ministry of Commerce and Agriculture was renamed in April, 1925) sent a letter to the Japanese Industrial Club requesting that it submit an opinion on opening an international conference in Japan. On June 6 , after deliberation by its board members, the Japanese Industrial Club replied that such a conference would "provide an opportune moment to advertise the present conditions of Japanese industry, receive knowledge from the other countries of the world, deepen mutual understanding with foreign visitors while exchanging good wishes with them, help Japanese industry gather momentum for development, and foster friendly relations with foreign countries. See Nihon Kogyo Kurabu, Kaiho II, 1916, p. 166.

48. The Engineering Association consisted of the following 12 bodies: Nihon Kogyokai, Nihon Tekkogyokai, Doboku Gakkai, Kahei Gakkai, Zosen Kyokai, Kogyo Gakkai, Eisei Kogyo Kyokai, Denki Gakkai, Denshin Denwa Gakkai, Kikai Gakkai, and Shomei Gakkai. Masao Kamo, Professor of Tokyo Imperial University, was the representative of the Kikai Gakkai (Mechanical Association).

49. For the outline of the first meeting of the preparatory committee, see Bankoku Kogyo Kaigi Junbi Iinkai, ed. Bankoku Kogyo Kaigi Junbi Iinkai giji sokkiroku (Stenographic record of the proceedings of the preparatory committee for the World Engineering Congress). Tokyo: Bankoku Kogyo Kaigi Junbi Iinkai, 1927.

50. Osakafu, Osakashi, Osaka Shoko Kaigisho, eds., Sangyo Gorika ni kansuru koenshu (Lectures on industrial rationalization), 1929, p. 2.

51. Ibid. Also see: Kobe Shoko Kaigisho, ed., Bankoku Kogyo Kaigi kinen koenroku (Lectures commemorating the World Engineering Congress), 1929.

52. Nikkan Kogyo Shimbunsha, Bankoku Kogyo Kaigi Sekai Doryoku 
Kaigi zen kiroku (Complete record of the World Engineering Congress and the World Power Conference), 1930, p. 50.

53. Nihon Kogyo Kurabu, ed., Nihon Kogyo Kurabu niju-go nen shi (25 years of the Japanese Industrial Club), 1943, vol. I, p. 98.

54. See Rinji Sangyo Gorikyoku monjo (Archives of the Ad Hoc Industrial Rationalization Bureau), 1932.

55. Nihon Noritsu Kyokai, ed., Keiei to tomoni: Nihon Noritsu Kyokai konsarutingu gijutsu yonju nen (History of management: 40 years of the consulting technology of the Japanese Management Association). Tokyo: Nihon Noritsu Kyokai, 1982, p. 25.

56. Ibid., pp. 27-29.

57. Nihon Shoko Kaigisho, ed. Sangyo gorika (Industrial rationalization), 1931, vol. 3, p. 91.

Translated by Atsuko Hirai 